Bryant University

Bryant Digital Repository

\title{
The Global Enforcement of Human Rights: the Unintended Consequences of Transnational Litigation
}

Andrea Boggio

Bryant University, aboggio@bryant.edu

Follow this and additional works at: https://digitalcommons.bryant.edu/histss_jou

Part of the Comparative and Foreign Law Commons, Human Rights Law Commons, Law and Society Commons, Litigation Commons, and the Torts Commons

\section{Recommended Citation}

Boggio, Andrea, "The Global Enforcement of Human Rights: the Unintended Consequences of Transnational Litigation" (2005). History and Social Sciences Faculty Journal Articles. Paper 89. https://digitalcommons.bryant.edu/histss_jou/89

This Article is brought to you for free and open access by the History and Social Sciences Faculty Publications and Research at Bryant Digital Repository. It has been accepted for inclusion in History and Social Sciences Faculty Journal Articles by an authorized administrator of Bryant Digital Repository. For more information, please contact dcommons@bryant.edu. 
Int'l J. of Human Rights, 2005, Vol. 10 (4), pp. 000-00

(C) 2005 Routledge

\title{
THE GLOB AL ENFORCEMENT OF HUMAN RIGHTS: THE UNINTENDED CONSEQUENCES OF TRANSNATIONAL LITIGATION
}

\author{
ANDREA BOGGIO*
}

\begin{abstract}
In the last few years, a growing number of individuals whose basic rights are violated have filed transnational human rights claims in foreign countries. By placing the individual as a holder of basic rights at the core of the process of development, the capability approach, as put forward by Amartya Sen and Martha Nussbaum, provides a fertile theoretical framework to assess translational human rights litigation.

The paper shows that transnational claims are problematic in two regards: 1) They undermine development by discouraging foreign companies from investing in countries that are sources of transnational claims and by weakening local governments and judiciaries; 2) The conflict resolution process is inadequate because financial and practical constraints prevent stakeholders from directly participating in the process, and because assessing damages and enforcing award judgments will likely be unfair. The path to be taken involves developing a stronger rule of law, stronger local institutions and independent judiciaries in those developed countries where the violations of basic human rights take place.
\end{abstract}

Key words: Capability approach - human rights violations - transnational litigation multinationals - offshoring - Alien Tort Claims Act

\section{INTRODUCTION}

Violations of human rights raise both ethical and legal challenges. The capability approach - as put forward by Amartya Sen and Martha Nussbaum - persuasively advocates that human rights are an essential to development and that their violation is morally wrong and jeopardises the development process. Primarily dealing with issues of quality of life, gender inequality, welfare economics, well-being and human development, the capability approach provides a conceptual framework to analyze transnational human rights litigation. ${ }^{1}$ Transnational human rights litigation is a dispute resolution process exercise of jurisdictional power of courts in Country A to solve claims brought by one or more citizens of Country B for violations of human rights that took

\footnotetext{
* This is a revised version of the paper presented at the conference From Sustainable Development to Sustainable Freedom, 7-9 September 2003, University of Pavia, Italy. The author welcomes comments at boggio@stanfordalumni.org.
} 
place in Country B. Transnational claims thus aim to geographical fill the gap between the place where the human rights violation took place and the place where the legal claims are adjudicated. However, whether this dispute resolution process is the best arrangement to solve those disputes and fill the geographical gap is a controversial policy issue.

In this paper, I argue that, although a valuable tool to redress human rights violations, overtime transnational litigation may have a negative impact on the same individuals and societies that benefit from today's transnational lawsuits. Among the unintended consequences, transnational litigation may in fact undermine the development of LDC by rendering those countries less competitive from a legal standpoint and by weakening local governments and judiciaries. I then show that capability approach provides a valuable ethical framework to reason about the policy issues arising out of transnational human right litigation. I then conclude that the capability approach suggests that favouring local adjudication through capacity building instruments is a superior dispute resolution process to transnational human right litigation.

\section{THE CAPABILITY APPRO ACH AND HUMAN RIGHTS VIOLATIONS}

The capability approach places the individual as a holder of basic rights at the core of the process of development. Thus, rather than seeing the individual aspects of the civil and political human freedoms as opposed to the collective aspects of the social and economic human rights, the two are approached as an integrated and mutually interdependent whole. The basic idea is that '[d]evelopment can be seen . . . as a process of expanding the real freedoms that people enjoy,' ${ }^{2}$ or, in Sen's jargon, people's capabilities. The capabilities are defined as 'what people are actually able to do and to be, ${ }^{3}$ or the opportunities to undertake actions and activities that the capabilities' holders want to engage in and be whom they want to be. This broad approach emphasises the relevance of the whole array of human capabilities in development processes, which list comprises social, cultural and economic capabilities such as the right to health, the right to food and the right to livelihood. The capabilities are thus conceptually distinct from the 'achieved functionings,' i.e. to transform the capabilities in actions and conditions of the real such as working, resting, being literate, being healthy, being part of a community, being respected. Under the capability approach what is ultimately important is that people have the freedom to choose what they want to do and be, and that social institutions should put them in the position to enjoy those freedoms or capabilities and to be free to choose individually which capabilities ought to be transformed in functionings. ${ }^{4}$

The capability approach thus provides a fertile framework for policy analysis. Public policies, market mechanisms and social institutions are evaluated to be good and just insofar as they expand people's capabilities consisting of their opportunities and choices to lead valuable human lives. In other words, social arrangements should ideally aim at expanding the people's capabilities at the greatest extent possible. Policies should thus aim at putting the capabilities' holders in the position of freely making choices. Limitations to their freedoms are suspect. Consequently, people should have right to their individual capabilities. 
Scholars of the capability approach have discussed at length the relationship between the human capabilities and human rights. ${ }^{5}$ Although Sen and Nussbaum are in disagreement on whether certain basic capabilities are morally required, both philosophers agree that a certain degree of capabilities - a threshold degree - should be afforded to all human beings to put them in the condition of living a decent human life. In Sen's language, such amount of capabilities is called 'basic capability' and '[it] is intended to separate out the ability to satisfy certain crucially important functionings up to certain minimally adequate levels. ${ }^{6}$ On the other hand, Nussbaum argues that people are entitled to central human capabilities, which are formally enumerated in form of list, ${ }^{7}$ which should serve as 'a foundation for basic political principles that should underwrite constitutional guarantees. ${ }^{, 8}$ Thus every society should strive to guarantee to its members a set of entitlements including capabilities such as living a long life and avoiding premature death, having good health and adequate nourishment, freedom of movement, freedom from assault, freedom of choice regarding sexual matters, to use one's senses, imaginations thinking and practical reason, and to engage in various forms of social and political relationships. ${ }^{9}$ Although the differences between the major thinkers behind the capability approach are not trivial, ${ }^{10}$ for the purpose of this paper, both scholars advocate the legal recognition of basic human entitlements or capabilities, whose infringements would be considered a violation of a basic human right.

\section{THE LIMITS OF LEGAL ADJUDICATION OF HUMAN RIGHTS VIOLATIONS}

Everyday, many individuals are unfortunately denied their basic human rights. The Human Development Report 2000 notes that, 'Of all human rights failures today, those in economic and social areas affect by far the larger number and are the most widespread across the world's nations and large numbers of people.' ${ }^{11}$ Classic Western legal theorists think that the legal systems should provide the environment where social and economic human rights grow as integral part of development by empowering the capabilities' holders of a right to claim to legal redress for the violations of their basic human freedoms and rights. ${ }^{12}$ In other words, legal systems shall provide both remedies and a process to redress the violations of human rights. In fact, exercising the right to claim legal redress gives rise to a dispute resolution process that aims at filling the gap between the claim and the remedies available under the law.

In the last few years, individuals of countries that do not afford these such basic human rights - in most cases less developed countries (LDCs) - have increasingly sought legal redress by filing transnational human rights claims. Because of a weak rule of law and the lack the domestic legal institutions that can provide reasonable redress to those claims, claimants seek justice in foreign jurisdictions where such preconditions exist. Thus, British judges have adjudicated claims brought by South-African asbestos miners because of their asbestos-related injuries and U.S. judges have adjudicated claims brought by groups of Burmese, Latin and Central American workers for the violations of their basic rights while working in their countries for U.S. and European companies. 
Transnational litigation often provides the only avenue to provide legal redress in the form of economic and non-economic compensation - to the victims of human rights violations in LDCs and to stop the violators from infringing upon individuals' rights. The growing substitution of foreign labour for domestic labour, i.e., offshoring especially in those countries were hourly wage are significantly lower that in Western societies - suggests that transnational litigation will be pursued more often. As on corporate consultants put it, 'the economics of offshoring are just too compelling to ignore if does right. ${ }^{\text {"3 }}$ McKinsey cites two examples to support the claim. 'BMW's plant in South Africa employs the same line of attack. Operating in these countries often requires extra training for workers-BMW spends three to five times more on training in South Africa than it does in its other plants - but wage differences more than offset that cost.' Moreover, 'a leading U.S. personal-computer manufacturer created telephone- and e-mail-based customer service centres in India to provide technical support. In addition to saving more than $\$ 100 \mathrm{~m}$ annually, it has significantly increased the proportion of customer problems it resolves. ${ }^{14}$ This prediction might be particularly accurate because countries offering lower hourly wages area often not on the forefront of acknowledging and enforcing human rights violations. In the next section, I discuss some of the transnational cases that have been already brought in the United States and in the United Kingdom.

\section{TRANSNATIONAL HUMAN RIGHTS LITIGATION}

Although numerous kinds of claims fall under the notion of transnational human rights litigation, I focus my analysis on human rights violations substantiating in personal injuries arising out of employment conditions. ${ }^{15}$ Foreign citizens have been able to bring personal injury actions against foreign companies before courts in the United States and in the United Kingdom for negligent actions an omissions committed in the country where the plaintiffs reside seeking compensation of the infringements of their basic rights. Tort laws and specific statutes both in the United States and in the United Kingdom provide the basis for filing transnational claims. U.S. federal courts may in fact hear 'any civil action by an alien for a tort only, committed in violation of the law of nations or a treaty of the Unites States." ${ }^{16}$ Similarly, British common law allows foreigners to file their claims in British courts unless the defendant can show that the foreign forum is more suitable 'for the interests of all the parties and the ends of justice. ${ }^{17}$ Involving the combined application of national laws, foreign laws, and principles and rules of public international law, the adjudication is always carried out by foreign judicial systems and judges appointed by foreign governments who apply the procedural law of the location of the trial. The next two sections will discuss examples of transnational lawsuits brought in the two cited jurisdictions.

\section{A. The United States: Litigation under the Alien Tort Claims ACT (ATCA)}

The Alien Tort Claims Act allows foreign plaintiff to file tort claims in US Federal Courts. 'The district courts shall have original jurisdiction of any civil action by 
an alien for a tort only, committed in violation of the law of nations or a treaty of the Unites States. ${ }^{18}$ Thus, ATCA grants U.S. courts jurisdiction over foreign defendants in tort actions where plaintiffs assert a tort claim that violates a U.S. treaty or the 'law of nations. ${ }^{19}$

Beginning with Filartiga ${ }^{20}$ the long-dormant ATCA increasingly presented the prospect of enforcing international human rights violations through the U.S. federal courts. In Filartiga, a torture claim was brought against a former official of the government of Paraguay. The Second Circuit Court of Appeal held that an alien could sue in U.S. federal court for a 'tort' that violates the 'law of nations. ${ }^{21}$ The court found that torture violated the law of nations, ${ }^{22}$ and avoided the necessity of ruling on whether a private party could be liable since the defendant had been a state actor when the violations occurred. ${ }^{23}$

Since Filartiga, courts 'have also recognised that the statute applies to commanders as well as to the actual torturer, to organizations and corporations as well as to individuals, and to private personas well as to government actors.' Thus taking advantage of the modern doctrine of ATCA that born out of atrocious human rights abuses, several foreign plaintiffs sought to redress human rights violations that had taken place in the workplace. The first of these new ATCA lawsuits was filed in September 1996 by a group of Burmese against a U.S. company, Unocal. ${ }^{24}$ Plaintiffs alleged that Unocal was liable for international human rights violations perpetrated by the Burmese military by knowingly using forced labour to construct a natural gas pipeline across the Tenasserin region of Burma, which was created to natural gas from oil fields off the coast of Burma to the Thai border. Although plaintiffs' claims had been initially dismissed on summary judgment by District Court, in September 2002, the Ninth Circuit Court of Appeals rendered a landmark decision against Unocal, allowing plaintiffs to proceed to trial in federal court.

While the allegations against Unocal for using slave labour in Burma are litigated, a series of cases have been brought under the ATCA and the Torture Victim Protection Act (TVPA) ${ }^{25}$ alleging that some of the largest American corporations have knowingly participated in human rights violations while operating business in foreign countries. The case law was in fact allowing claims against private corporations when it had engaged 'in one of the core international law violations that do not require state action, such as genocide or slavery, or when it acts in complicity with a state actor committing any of the core violations. ${ }^{26}$ Thus, Exxon Mobil was named defendant by a group of Indonesian citizens for allegedly committing violations of human rights by recruiting one or more military units to provide security for its gas extraction and liquefaction project. $^{27}$ Plaintiffs' theory of liability is that Exxon is liable either because the defendant either employed members of the military units or based on the liability theories of respondeat superior or vicarious liability. Moreover, Coca-Cola was named defendant in a lawsuit filed by five Colombian nationals and a Colombian labour union for tortuous acts allegedly consisting in using paramilitaries to engage anti-union violence. ${ }^{28}$ Fresh Del Monte Produce was named defendant in a lawsuit filed by five former union leaders who were allegedly tortured and detained in Guatemala. ${ }^{29}$ Finally, DynCorp was named 
defendant in a lawsuit filed by the International Labor Rights Fund on behalf of more than 10,000 Ecuadorian citizens who are 'suffering health effects as a result of the company's spraying of a toxic herbicide on their communities as part of a larger operation to eradicate coca plants in Columbia. ${ }^{30}$

All these cases allege blatant violations of human rights that raise important legal issues of whether U.S. courts have jurisdiction over all the claims, whether the defendants owed a duty of care to the foreign victims of human rights violations and, finally, whether the American corporate parent should be held liable for the actions of the foreign subsidiary. All these issues have been major procedural barriers to foreign plaintiffs: 'Most of the post-Filártiga cases have been dismissed, most often for failure to allege a violation of international recognised human rights, for forum non conveniens, or because of the immunity of the defendant. ${ }^{31}$

Courts are in the process of addressing them as they are presented in courts. Although predicting the future of ATCA litigation is difficult, both advocates for and against ATCA litigation ${ }^{32}$ share the common view that U.S. courts are increasingly favourable to transnational claims and that it is reasonable to assume that, in the next five years, ATCA cases will be increasingly filed and U.S. courts asked to adjudicate them. Given the sympathetic support of U.S. courts, it is also foreseeable that plaintiffs will overcome today's procedural barriers, and that judges and juries will be eventually asked to define the scope of the actionable violations and the standard of liability.

Today the scope of ACTA litigation has been certainly limited to certain major human rights violations. Courts have held that ATCA provides a cause of action as 'plaintiffs . . . allege a violation of 'specific, universal, and obligatory' international norms as part of [their] ATCA claim. ${ }^{33}$ Defining the substance of the 'law of nations' is a however complex tasks that U.S. courts still have to perfect. In Filartiga, the Second Circuit held that ' $[\mathrm{t}]$ he law of nations "may be ascertained by consulting the works of jurists, writing professedly on public law; or by the general usage and practice of nations; or by judicial decisions recognizing and enforcing that law." 34 The law of nations may be defined as,

[A] system of rules, deducible by natural reason, and established by universal consent among the civilised inhabitants of the world . . . to insure the observance of justice and good faith, in that intercourse which must frequently occur between two or more independent states, and the individuals belonging to each. ${ }^{35}$

Judge Edwards of the D.C. Circuit pointed out that deriving concrete standard of liability from 'amorphous' international law norms places 'an awesome duty on federal courts. ${ }^{, 36}$ If there is some agreement that torture, murder, slavery, rape and genocide are within the notion of 'law of nations,' international consensus is lacking on many issues crucial to human rights concerns such as a living wage, minimum health and safety standards, maximum hours, and sexual harassment. ${ }^{37}$ However, "[ATCA] presents the potential to address claims involving intentional physical or mental harm, but is not likely to reach less extreme but much more common claims, including abominable working 
conditions. ${ }^{38}$ In other words, the scope of the notion of 'law of nations' is evolving and expanding overtime, eventually providing a transnational tool to the redress of a wide range of human rights violations.

When cases will reach a stage where courts or juries will be required to make a determination of liability, the central question will be to define under which standards of liability under which the defendants should be tried. It is very likely that the law of the forum - U.S. law in ATCA cases - will become the law to be applied to the facts of the case. Most of ATCA cases are, in fact, tort cases, thus requiring a determination of whether or not the defendant knowingly or negligently breached the duty of care owed to foreign victims of human rights violations. Although, under the majority rule, 'ATCA not only confers jurisdiction but also creates a cause of action, ${ }^{39}$ U.S. federal judges will be very likely to find those standards in domestic law, especially of the plaintiff's legal system provide very limited protection to the victims. They will do either in bench trials or in instructing juries, or in deciding over an appeal as in the Unocal case.

indeed, the published ATCA opinions support my claim that the process I describe is taking place. Thus, the Ninth Circuit defined 'forced labour' - which the judges considered to be a violation of the 'law of nations' - by making reference only to U.S. case law and to the U.S. Constitution, without even trying to capture a more widespread, supranational notion of 'forced labour.' ${ }^{40}$ Furthermore, if juries will be asked to make a determination of liability, jurors will likely decide by using their natural mindset, the perspective of the average American juror. Furthermore, the actors of the litigation process are invariably lawyers and judges trained in domestic law, admitted in the domestic jurisdiction, and daily practicing domestic law. Thus, they will likely litigate the case as if they were ordinary civil actions. Finally, defendants' actions will be found 'reasonable' if complying with American standards. In sum, if U.S. courts will ever deal with the substance of ATCA claims, in the absence of clear agreement of international lawyers and scholars, American corporation will likely to be held liable as if they were conduction business in the United States or any other developed country.

\section{B. The United Kingdom: The South-African ASbestos Litigation (LubBe V. CAPE) ${ }^{41}$}

English common law allows transnational human right claims. 'Traditionally English courts did little to discourage litigants form choosing to litigate in England, when the case was brought there consistent with English jurisdictional rules. ${ }^{42}$ In 1972, Lord Denning stated that,

No one who comes to these courts asking for justice should come in vain.

To rights to come here is not confined to Englishmen. It extends to any friendly foreigner. ${ }^{43}$

Although this liberal view has partially eroded over the past two decades, foreign claimants are denied access to British courts only if the defendant can show that the 
foreign forum is more suitable 'for the interests of all the parties and the ends of justice. ${ }^{44}$ Such limitation is known as the doctrine of forum non conveniens.

This jurisdictional barrier did not dissuade a group of asbestos victims from filing personal injury lawsuits in the English High Court. Thus, in February 1997, five miners from Prieska and Penge filed claims to recover damages in court for personal injuries caused by the exposure to asbestos fibres in the course of their employment. 'The claims were based principally on the negligent control of the company's world-wide asbestos business from England and failure to take measures to reduce asbestos exposures to a safe level. ${ }^{, 45}$ The complaint alleged that the defendant as a parent company had failed to discharge its duty to ensure the compliance with proper health and safety standards by its overseas subsidiaries.

The defendant, Cape Ltd., had directly owned some of its South African operation for many years. By 1948, the company had restructured, so that its mining and manufacturing operations were owned by South African subsidiaries. In 1979, Cape sold its South African asbestos mining subsidiary, and, in 1989, its remaining interests in the manufacturing subsidiaries. ${ }^{46}$

Two Court of Appeal and two House of Lords decisions were necessary to dismiss the defendant's argument that British courts were a forum non conveniens, and to establish the right of South African miners to have their cases heard. ${ }^{47}$ On appeal before the House of Lords, the plaintiffs eventually succeeded in establishing the English courts' jurisdiction over the claims. The House of Lord ruled unanimously that, although South African courts were clearly the more appropriate forum for the trial, substantial justice would not have been served if the claims were litigated in South Africa. Under the governing law, claims should be dismissed on forum non conveniens arguments if a twoprong test is satisfied: (1) only the foreign forum is more appropriate, and (2) justice is likely to be served in the appropriate forum. The highest British court concluded that South African courts were not the most appropriate forum because there was no evidence that legal aid would have been available to the miners. Lord Bingham noted that,

If these proceedings were stayed in favour of the more appropriate forum in South Africa the probability is that the plaintiffs would have no means of obtaining the professional representation and the expert evidence that would be essential if these claims were to be justly decided. This would amount to a denial of justice. ${ }^{48}$

Furthermore, there was evidence that suggested that, under the circumstances of the case, legal representation would be likely not available if the claims were to be litigated in South Africa. Second, South African law did not provide specifically for group actions, thus raising suspicions about the ability of South African claims to provide an adequate and fair setting for the trial. ${ }^{49}$

Although plaintiffs successfully established their right to have their claims heard by U.K. judges, the over 7,500 claims were never litigated, nor in England neither in 
South Africa. The parties eventually settled the case in December 2001 after long negotiation. ${ }^{50}$ Under the settlement agreement,

[The defendant] has agreed to pay a total of $£ 21$ million into a Trust fund to be established in South Africa which will make payments to those who may show that they have suffered from asbestos-related disease . . a as a result of working at, or living in the vicinity of, one of Cape's former mining, milling, or manufacturing operations in South Africa. ${ }^{51}$

Under the agreement, compensation is available not only to the claimants who took part in the English litigation, but also to all victims who satisfy the conditions set by the trust. The level of compensation is linked to the severity of the disease: ' $[\mathrm{M}]$ esothelioma awards being the highest (about $£ 5,250$ total maximum); asbestosis (about $£ 3,250$ total max); pleural thickening/pleural effusion (about $£ 1,600$ total max), pleural plaques (about $£ 700$ total max). ${ }^{52}$

Although the litigation and the negotiation were successful, enforcing the settlement has proven to be a complex task. Under the agreement, the $£ 21 \mathrm{~m}$ will not be paid in one lump sum, but the defendant was supposed to make available the first $£ 11 \mathrm{~m}$ in June 2002 only if various conditions are satisfied, the most important being the South African Government's commitment of not funding future legal claims against Cape and of not pursuing Cape 'for any cost of rehabilitating its former asbestos mines. ${ }^{53}$ Under threat of bankruptcy, Cape failed to pay the settlement for several months. However, in June 2003, the High Court eventually approved the compensation settlement at the end of the hearing. Cape handed over bankers' drafts for $£ 7.5 \mathrm{~m}$, which victims to receive payments during summer $2003 .{ }^{54}$

\section{THE UNINTENDED CONSEQUENCES OF TRANSNATIONAL HUMAN RIGHTS LITIGATION}

In the remains of the paper, I shall investigate under the lenses of the capability approach the policy question of whether transnational litigation is better suited to redress human rights violations. The central idea of the capability approach is that '[d]evelopment can be seen . . . as a process of expanding the real freedoms that people enjoy. ${ }^{55}$ In other words, there is no development without freedom. My analysis will be thus proceeds from the point of view of the capabilities' holders who are entitled to basic freedoms that human rights violations infringe. Those individuals are nonetheless the citizens of those LCDs where the violations took place. Transnational human rights cases are litigated in their interest - they are the stakeholders with the greatest interest in dispute resolution process - and the expansion of their freedoms creates development for them and their countries. Thus, the capability approach places the holders of basic freedoms and rights at the centre of the policy analysis, and consequently of my analysis of human rights transnational litigation as dispute resolution process.

From the point of view of capabilities' holders, this litigation has the undeniable merit of providing judicial redress to violations that, without the involvement of foreign 
judicial systems, would be unheard in courts. In fact, the victims would not have access to justice in their home countries, and would receive no compensation. Moreover, the perpetrators of the violations would not be held accountable. In today's ineffectiveness of many judicial systems around the world, stopping transnational claims would impair the ability of the capabilities' holders to seek legal redress and of many countries to move toward development. However, the policy analysis of transnational claims should take into account a long-term perspective. The inquiry should thus focus on whether transnational litigation is the dispute resolution process that better protects the interests of the holders in the long run.

The next section will thus critically assess, from a policy perspective, the ability of transnational human rights litigation to serve the interests of the holders. I will argue that transnational human rights litigation affects development in at least in two regards. First, it discourages foreign companies from investing in countries that are sources of transnational claims. Second, it weakens local governments and judiciary. Each argument will be examined separately.

\section{A. Transnational Claims undermine deVElopment BeCause Countries THAT ARE SOURCES OF TRANSNATIONAL Litigation ARE LESS COMPETITIVE}

In a long term perspective, tran snational human rights litigation may have a negative impact on development: Countries that are sources of transnational litigation may become, overtime, less competitive than countries that afford domestic, legal redress to human rights violations. ${ }^{56}$

As many commentators suggest, this litigation is moving its early steps very often with insurmountable difficulties. However, it is likely that courts will be increasingly asked to adjudicate those kinds of claims in the next few years. As I argued earlier in the paper, overtime Western courts will likely hold Western companies accountable for their actions and omission in LDCs under the legal standards that they apply in domestic cases. In other words, Western corporations will be held accountable to identical standards whether investing in developed countries or in LDCs that are sources of transnational claims. For instance, if the South African case had been tried rather than settled, the English judges would have been asked to decide whether or not Cape was negligent in exposing South African miners to an unreasonable risk. The lawyers would have probably borrowed information - medical link between asbestos and several diseases, knowledge of asbestos toxicity, availability of safer technologies - largely from the earlier asbestos litigation in U.K. courts. Moreover, although contextualizing the information gathered along the litigation process to South Africa, the U.K. judges would have likely held the defendants liable for damages based on U.K. tort law rather than South African negligence principles.

This suggestion logically leads to investigate its implications on the LDCs involved. In my analysis, I assume that courts in a LDC, Country Z, ordinarily hear cases that qualify as human rights violations, while courts in Country A do not afford similar legal protection. Country $\mathrm{Z}$ is thus not a source of transnational litigation; Country $\mathrm{A}$ is. 
Country $\mathrm{Z}$ would thus have a legal and judicial system capable of holding domestic and foreign violators of human rights accountable for their misconducts. Because both the rule of law and a politically-independent judiciary are in place, Country Z's system works and its policymakers are in the position of being able to draft less rigorous standards than Western democracies, in a fashion that will attract foreign investors without compromising basic individual freedoms. ${ }^{57}$ These countries could thus make use of their legal systems as tools to attract foreign investors by adopting and implementing liability standards more liberal than countries with similar level of development yet unable to provide internal legal redress. In the other hand, LDCs that are sources of transnational human rights litigation in the past or where the lack of rule of law and of an independent judiciary strongly suggest that, in case of human rights violations, lawsuits will be filed in the country where the parent company has its headquarters, are not in the position to attract foreign investors, who will be likely to be held accountable in their home courts based on more rigorous standards. Overtime, the latter countries would attract fewer investments, thus undermining their economic development. In sum, countries with a weaker rule of law and institutions and high risk of generating transnational lawsuits will attract less investments that countries where a greater level of domestic redress is afforded to citizens whose human rights have been violated. Western investors will in fact be likely attracted to LDCs with lower - yet respectful of basic human rights standards of liability for workplace misconducts.

\section{B. Transnational Claims UNDERMINE DEVElopMENT BY WEAKENING LOCAL GOVERNMENTS AND JUDICIARIES}

Transnational human rights litigation may weaken local institutions of the LDCs whose citizen bring the claims in foreign courts. It may in fact reduce their ability to regulate domestic matters and to negotiate matters of foreign policy with the governments of the countries where the litigation takes place.

In transnational litigation, a foreign judge determines whether or not a violation of a human right took place in the country where the negligent actions and omissions occurred. To conclude that a violation took place, the foreign judge shall determine what the defendants should have done to avoid violating a human right. Thus transnational litigation turns into 'an exercise in extraterritorial jurisdiction: courts in one jurisdiction sit in judgment on the propriety and legality of behaviour in another jurisdiction., ${ }^{58}$

The foreign judge may do so by making reference to various sources, namely the 'laws of nations,' to the legal standards of either countries involved, or to international law and agreements. However, whichever legal basis the court adopts, the political significance of its action does not change. Foreign judge are in essence making a normative assessment of the other legal system. In their opinions, foreign judges are thus stating what the law of the country where the violation took place should be. The institutions of LDCs that are sources of transnational litigation are consequently limited in their ability to regulate internal matters. 
Transnational litigation has also a second negative impact on the institutions of LDCs that are sources of those claims. It weakens the role of LDC governments in shaping foreign policy. The argument has been made from United States' perspective, by saying that ATCA litigation undermines U.S. foreign policy. A commentator argued that,

The use of the statute for human rights litigation, including these corporate suits, inherently involves policy decisions that are better made by the executive and legislative branches, not the judicial branch . . . There's a real danger that these lawsuits, if they continue to expand as they have, could truly interfere with relations that we have with foreign governments. ${ }^{59}$

This is certainly an important issue. Over the years, several ATCA lawsuits have brought to the defendant stand several foreign government officials. From a constitutional point of view, the relationship between the United States and foreign governments is left to, and better served, by Congress and the President rather than federal courts. If this argument does not directly affect the interests of the main stakeholders of the process, i.e. LDC citizens, the reverse does. By adjudicating on the liability of Western companies and local governments, foreign courts step into foreign policy affairs, thus limiting the role of local governments in the shaping their foreign policy. Governments of LDCs generating ATCA claims are in fact not in a position of negotiating with foreign governments' trade agreements and other matter of foreign policy involving trade issues because foreign judges eventually have the last word on the matters to be negotiated. ${ }^{60}$

\section{Transnational Human Rights Litigation is an InADEQuate Conflict RESOLUTION PROCESS}

The success of transnational claims has often been praised as a great victory for the victims of the violations. It is irrefutable that this form of litigation often provides with only avenue for redress available. Without access to foreign courts, many people around the world would be deprived of a chance to have their claims heard, the damages would not be compensated, and the violations not be prevented from happening again. However, is transnational litigation the best dispute resolution process available for the future? I am addressing this question by looking at how the capability approach addresses this policy challenge. After showing that the capability approach points out that transnational litigation is inadequate from a political standpoint, I now turn to transnational claims as a specific dispute resolution process. Several factors suggest it is an inadequate dispute resolution process in light of the capability approach's quest for expansion of people's capabilities. ${ }^{61}$ Key aspects of the adjudication process in foreign courts support my argument that local policymakers and international organizations and lawyers should direct their effort towards strengthening domestic dispute resolution rather than relying on transnational litigation to redress human rights violations.

\section{Participation}


Dispute resolution scholarship points out that participation of the victims in the dispute resolution process should not be overlooked. Studies show that domestic litigants in the United Kingdom and in the United States are overall dissatisfied with the litigation process and that their judgments are based on their perception of the fairness of the procedures used in reaching decisions. ${ }^{62}$ In fact, the empirical literature shows that the opportunities to comprehend and actively take part in proceedings and whether they have control over the procedure and the outcome influence the claimants' perception of the process. Under the capability approach, people shall have the capability to take part of the process that adjudicates their rights and freedoms. Transnational litigation offers, however, little possibility to meet those (procedural) needs. Both financial and practical constraints prevent stakeholders from directly participating in the process. Moreover, even if in the material conditions to attend the trial, claimants would be in the difficult position of understanding a process that takes place in a different language and that is that expression of different cultural, political and legal traditions. These reasons alone raise concerns of adequacy of the process, and of procedural justice of transnational litigation. Furthermore, the lead actors of the process are foreign lawyers, judge, and jurors, interpreting the process with their own Western, cultural values.

\section{Damages}

American or English courts will soon be required to make a determination of liability and, if liability is established, to award reasonable compensation to the victims. As discussed above, such determination involves important issues of what standards of liability foreign judges should apply. They will likely apply standards that are commonly shared in the communities where they live and exercise their professions. ${ }^{63}$ Similarly, once the court finds the defendants liable, it will assess compensation by awarding the damages that are generally awarded in similar circumstances in the jurisdiction where the trial takes places. Courts could not act differently. As a consequence, the liquidated damages will be much higher than those that the claimants could recover by litigating the same claims in their national court.

This conclusion creates practical and theoretical problems. From a practical standpoint, this system provides incentives for forum shopping and race to Western jurisdictions generating concerns of efficiency of the dispute resolution arrangement and of allocation of resources. From a theoretical standpoint, the awards raise issues of fairness with respect to the victims of the jurisdiction where the litigation takes place. They would receive relatively smaller amounts if compared to their economic losses. Assuming the harm inflicted is equal, LDC victims would in fact enjoy a greater difference between the damages awarded and the extent of the economic loss suffered than victims situated in similar positions and living in the jurisdiction where the litigation takes places. ${ }^{64}$

\section{Enforcement}


Lastly, transnational litigation potential raises issues of enforcement of the judgment. Enforcement is a process aimed at materializing the practical results of a judgment. In the case of damage awards, the enforcement process aims at transferring the amount of liquidated damages from the pockets of the liable defendant to the plaintiff. If enforcement of a foreign judgment is sought, the general principle of international law applicable in such cases is that a foreign state claims and exercises the right to examine judgments for four causes: (1) to determine if the court had jurisdiction; (2) to determine whether the defendant was properly served; (3) to determine if the proceedings were vitiated by fraud; and (4) to establish that the judgment is not contrary to the public policy of the foreign country. ${ }^{65}$

Although enforcement has not been an issue in transnational cases so far because all of them in earlier stages of the litigation process or have been settled, transnational litigation raises issues of enforcement of the judgment. If the litigation were to take place in the countries where the victims reside, the final judgment would be enforced locally. However, the defendants' largest assets are commonly in the United States or in the United Kingdom, thus creating the need for a transnational enforcement. In this scenario, the judgment would be deemed 'foreign' by U.S. and U.K. courts, thus triggering their right to examine the judgments.

On the other, litigating claims in the jurisdiction where the defendant has the majority of its assets certainly facilitates damage awards' enforcement. The assets of the liable defendant are easy to locate, and the judgment has power to be enforced without further scrutiny. Nonetheless, this process may raise pressing issues. First, allocating the money in the defendant's pocket to foreign claimants may jeopardise the ability of domestic victims of tortuous acts of recovering damages awarded in their favour. Thus, compensating citizens of other countries for negligent actions an omissions that took place outside the jurisdiction and depriving domestic victims creates a tension between the social and the individual dimension of justice. In past few years, several large American and British companies have filed for bankruptcies as a result of the large number of personal injury lawsuits filed, mostly by domestic plaintiffs, against them. ${ }^{66}$ If transnational litigation targets 'at risk of bankruptcy' companies, damages awards in favour of foreign victims - although technically 'domestic' - would raise issues of fairness. In fact, if considered in its social dimension rather than the perspective of the individuals actors involved, scholars have pointed out that the tort system allegedly accomplishes goals of social justice. And those ends would be partially frustrated by compensating foreign victims. Although not frequent, tensions between domestic and foreign plaintiffs have already emerged in two U.S. bankruptcy proceedings. ${ }^{67}$ The best way to proceed should probably be found in favouring domestic resolution of controversy and in improving the system of satisfaction of transnational creditors whose monetary entitlements arise out of domestic judgments. Furthermore, LDC could request to secure the potential liability following a finding of tort liability for violations of human rights to foreign investors at the time of the initial investment. ${ }^{68}$ 


\section{CONCLUSION: STRENGTHENING THE RULE OF LAW}

Infringing basic human rights is despicable, and simply morally wrong. The capability approach aims at giving people the necessary conditions of a life with human dignity. The capability approach thus provides a powerful framework to impose a moral duty to stop and redress those violations, and to prevent them from happening in the future. Shaping mechanisms to translate the ethical commands into practical actions is a problematic task. Legal redress seems to be, at least in Western commentators' and lawyers' mind, the mechanism that best serves these moral ends.

In the last few years, individuals of countries that do not afford basic human rights have increasingly sought redress by filing transnational human rights claims. Because of the lack the rule of law and legal institutions that can reasonably provide redress to those claims, individuals whose basic rights are compressed pursue their claims where such preconditions exist. In the paper, I argued that, although transnational claims benefit LDC victims in the present time - because their harms would otherwise not be redressed overtime they create unintended consequences in terms of weakening the economic and institutional development process of LDC and by providing an inadequate dispute resolution process.

Transnational litigation should thus not be seen as the optimal mechanism of redress of human rights violations in LDC in the future. By contrary, local redress would better serve the moral goals that the capabilities approach proposes. Building stronger local institutions and judiciaries and a stronger rule of law in LDC is thus not only the best policy solution but is also a moral obligation of the parties involved in the process whether from the North or the South. In this regards, both stakeholders - local and international NGOs and foreign investors - and international organization - the UN and the World Bank above all ${ }^{69}$ - should be fully engaged in investing in institution and capability building in order to create the precondition for local redress of basic human rights violations, a redress able to stop and prevent those violations from happening again. $^{70}$

\footnotetext{
${ }^{1}$ See, Amartya K. Sen, 'Well-Being, Agency and Freedom: the Dewey Lectures, 1984', Journal of Philosophy, Vol.32 (1985), pp.169-221; Id., Commodities and Capabilities (Amsterdam: New Holland 1985); Id., Inequality Re-examined (Cambridge: Harvard University Press 1992); Martha C. Nussbaum, Sex and Social Justice (Oxford: Oxford University Press 1999); Id., Women and Human Development: The Capabilities Approach (Cambridge: Cambridge University Press 2000).

${ }^{2}$ Amartya K. Sen, Development as Freedom (New York: Alfred A. Knopf 1999), p.1.

${ }^{3}$ Nussbaum, Women and Human Development (note 1).

${ }^{4}$ The capability approach is thus a liberal theory emphasizing the role of people's freedoms.

${ }^{5}$ On the distinction between human rights and capabilities, see, Amartya K. Sen, 'Elements of a Theory of Human Rights', Philosophy \& Public Affairs, Vol.32 (2004), pp.315-56.

${ }^{6}$ Amartya K. Sen, 'Capability and Well-Being', in Martha C. Nussbaum \& Amartya K. Sen (eds), The Quality of Life (Oxford: Clarendon Press 1993), p.41.

${ }^{7}$ Martha C. Nussbaum, 'Capabilities as Fundamental Entitlements: Sen and Social Justice', Feminist Economics, Vol.9 (2003), pp.33-59.
} 
${ }^{8}$ Nussbaum, Women and Human Development (note 1) pp.70-1.

${ }^{9}$ Ibid. pp.78-80; Nussbaum, 'Capabilities as Fundamental Entitlements' (note 7) p.41.

${ }^{10}$ David Crocker, 'Functioning and Capabilities: The Foundation of Sen's and Nussbaum's Development Ethics', Political Theory, Vol. 20 (1992), pp. 584-612; John M. Alexander, 'Capabilities, Human Rights and Moral Pluralism', International Journal of Human Rights, Vol.8, No.4 (2004), pp.451-69.

${ }^{11}$ Human Development Report 2000, United Nations Development Programme (2000), p.73.

${ }^{12}$ Ibid.

${ }^{13}$ Vinay Couto, 'An outsourcing flop', CBS News (Anthony Mason) June 23, 2004.

${ }^{14}$ Anonymous, 'Offshoring And Beyond', The McKinsey Quarterly No.4 Global Directions (2003),

$<$ http://www.mckinseyquarterly.com/article_abstract.asp $x$. $\mathrm{ar}=1367 \& L 2=21 \& L 3=33 \&$ srid $=6 \& g p=1>$

${ }^{15}$ My analysis does not include claims arising out of human rights violations such as torture, massacres and genocides, kidnapping, rape and political or military actions in general.

${ }^{16} 28$ U.S.C. § 1350, codifying Judiciary Act of 1789, § 9 (Sep.24 1789).

${ }^{17}$ Spiliada Maritime Corp. v. Cansulex Ltd. [1987] A.C. 460, 476.

${ }^{18} 28$ U.S.C. $\S 1350$.

${ }^{19}$ Ibid.

${ }^{20}$ Filartiga v. Pena-Irala, 630 F.2d 876 (2d Cir. 1980).

${ }^{21}$ Ibid. at 887.

${ }^{22}$ Beth Stephens, 'Upsetting Checks and Balances: The Bush Administration's Efforts to Limit Human

Rights Litigation', Harvard Human Rights Journal Vol.17 (2004), p.175.

${ }^{23}$ Filartiga, 630 F.2d at $889-90$.

${ }^{24}$ Unocal Corporation and Union Oil Company of California are collectively known as Unocal.

2528 U.S.C. $§ 1350$.

${ }^{26}$ Stephens (note 22) pp.176-7.

${ }^{27}$ John Doe v. Exxon Mobil, Co., NO 1: 01CV01357 (D. D.C. filed June 20, 2001) (filed under ATCA provisions). The violations imputed to Exxon include genocide, murder and torture.

${ }^{28}$ Sinaltrainal v. Coca-Cola, NO. 01-03208-CIV (S.D. Fla. filed July 21, 2001) (alleging violations of ATCA, RICO and the common laws of Florida and Republic of Colombia). The District Court later granted a motion for summary judgment filed by the defendants and dismissed a number of allegations. Sinaltrainal v. Coca-Cola, 2003 U.S. Dist. LEXIS 7136 (S.D. Fla. decided March 28, 2003).

${ }^{29}$ Villeda Aldana v. Fresh Del Monte Produce, NO. 1-3399-CIV (S.D. Fla. filed Aug. 30, 2001).

${ }^{30}$ Terry Collingsworth, 'Boundaries in the Field of Human Rights: The Key Human Rights Challenge: Developing Enforcement Mechanisms', Harvard Human Rights Journal Vol.15 (2002), p.195. The complaint, cited in the article, is Aria v. DynCorp, NO. 1:01CV01908 (D. D.C. filed Sep. 11, 2001) (filed under ATCA, TVA and international human rights law).

${ }^{31}$ Ibid. p.177.

${ }^{32}$ In the United States, both advocates pro and against ATCA claims have raised their voices. See Adam Liptak, 'U.S. Courts' Role in Foreign Feuds Comes Under Fire', N.Y. Times, August 3, 2003. The U.S. Government opposes such litigation as one representative of the Department of State recently said in Senate testimony,

The current litigation-based system of compensation is inequitable, unpredictable, occasionally costly to the U.S. taxpayer and damaging to foreign policy and national security goals of this country.

'Benefits for U.S. Victims of International Terrorism', Hearing before the Committee on Foreign relations, United States Senate, One Hundred Eighth Congress (1st session July 17, 2003)(testimony of William H. Taft IV, Legal Adviser of the Department of State), cited in Liptak's article. 
${ }^{33}$ John Doe v. Unocal Corp, 2002 U.S. App. LEXIS 19263 (9th Cir. 2002) (citing Papa v. United States, 281 F.3d 1004, 1013 (9th Cir. 2002) (emphasis added). See also, In re Estate of Ferdinand E. Marcos, Human Rights Litig., 25 F.3d 1467, 1475 (9th Cir. 1994).

${ }^{34}$ Filartiga, 630 F.2d at 880 (quoting United States v. Smith, 18 U.S. 153, 160-61, 5 L. Ed. 57 (1820)).

${ }^{35} \mathrm{~W}$. Blackstone, Commentaries on the Laws of England (University of Chicago Press 1979), Vol.4, p.66.

${ }^{36}$ Tel-Oren v. Libyan Arab Republic, 726 F.2d 774, 781 (D.C. Cir. 1984).

${ }^{37}$ Collingsworth (note 30) p.202.

${ }^{38}$ Ibid.

${ }^{39}$ Papa, 281 F.3d at 1013. But see, Tel-Oren, 726 F.2d at 774.

${ }^{40}$ John Doe v. Unocal Corp, 2002 U.S. App. LEXIS 19263 (9th Cir. 2002) (citing the Thirteenth

Amendment of the US Constitution and federal cases).

${ }^{41}$ C. G. J. Morse, 'Not in the Public Interest? Lubbe v. Cape Plc', Texas International Law Journal, Vol. 37

(2002), pp. 541-57.

${ }^{42}$ Ibid. p. 542.

${ }^{43}$ The Atlantic Star [1973] 1 Q.B. 364, 381-81 (Eng. C.A. 1972).

${ }^{44}$ Spiliada Maritime Corp., [1987] A.C., p.476.

${ }^{45}$ Richard Meeran, 'Liability of Multinational Corporations: A Critical Stage' (1999), < http://www.labournet.net/images/cape/campanal.htm>.

${ }^{46}$ Patrick M. Hanlon \& Matthew M. Hoffman, 'Availability of U.S. Courts for Asbestos Actions Arising out of NON-U.S. Exposures', A.L.I-A.B.A. Continuing Legal Education (2001), Vol. 33, pp.38-9.

${ }^{47}$ First, the Court of Appeal held in 1998 that five claimants could sue in the High Court. After 3,000 new claimants joined the proceedings, a second, different Court of Appeal held that the five and the group of new plaintiffs should sue Cape in South Africa and not in the United Kingdom.

${ }^{48}$ Schalk Willem Burger Lubbe (Suing as Administrator of the Estate of Rachel Jacoba Lubbe) and 4 Others and Cape PLC. and Related Appeals, 4 All E.R. 268 (H.L. 2000):

If these proceedings were stayed in favour of the more appropriate forum in South Africa the probability is that the plaintiffs would have no means of obtaining the professional representation and the expert evidence which would be essential if these claims were to be justly decided. This would amount to a denial of justice.

${ }^{49}$ For a through analysis of the legal implications of the case, see, Peter Muchlinski, 'Corporations in International Litigation: Problems of Jurisdiction and the United Kingdom Asbestos Cases', International and Comparative Law Quarterly, Vol.50 (2001), pp.1-25.

${ }^{50}$ Richard Meeran, 'Justice at Last for Asbestos Victims as Epic London Legal Battle Ends', $<$ http://www.leighday.co.uk/current.html\#London> (Dec. 21, 2001) (reporting that the following organizations and individuals have contributed in supporting the claims: the South African Government, national and provincial; NUM, the successors to the Anti-Apartheid Movement, a number of British politicians, Amnesty International and the Transport and General Workers Union, the Legal Services Commission for England and Wales, and the newly appointed Chairman of Cape, Paul Sellars).

${ }^{51}$ Ibid. ('The Trust will symbolically be called the 'Hendrik Afrika Trust' after one of the victims').

${ }^{52}$ Ibid.

${ }^{53}$ Ibid. ("Another condition is that Cape obtains the approval of its bankers and shareholders for the deal and that is able to raise the necessary finance.'). Cape will them make the other $£ 10 \mathrm{~m}$ available into the Trust over a period of 10 years at an annual rate of $£ 1 \mathrm{~m}$.

${ }^{54}$ Leigh Day \& Co., South African asbestos victims finally get their money (Press release June 30, 2003), $<$ http://www.leighday.co.uk/doc.asp?cat $=850 \& d o c=108>$. The same law firm is now bringing a claim in English courts on behalf of 650 Kenyan women who were allegedly raped by British army. Recently the 
lawyers scored a success by obtaining legal aid for the Kenyan clients, which will cover for the legal expenses of the case. See, Martin Plaut, 'Defending Africa's downtrodden', BBC News (July 3, 2003), $<$ http://news.bbc.co.uk/1/hi/world/africa/3039944.stm>.

${ }^{55}$ Sen, Development as Freedom (note 2) pp.38-41.

56 'Competition' is intended in a legal dimension as ability of one legal system to attract business over another because of the rules and regulation that are in place in each of the $\mathrm{m}$.

57 The underlying assumption is that legal standards should protect a core of basic human freedoms and then provide an increasing protection directly proportional to the level of economic development of the country.

${ }^{58}$ Jan Klabbers, 'Doing the Right Thing? Foreign Tort Law and Human Rights', Craig Scott (ed), Torture as Tort. Comparative Perspectives on the Development of Transnational Human Rights Litigation (Oxford: Hart Publishing 2001), p.556.

${ }^{59}$ Dan Eggen \& Charles Lane, 'White House Seeks to Curb Rights Cases From Abroad U.S. Fears Effect On Diplomatic Ties', Washington Post (May 30, 2003), p.A01 (emphasis added).

${ }^{60}$ Albeit with different arguments and with a different agenda, the Bush administration has put forward the similar claim that the interpretation of the ATCA by modern courts violates separation of powers rests on the argument that it constitutes an interference with executive branch foreign affairs powers.

${ }^{61}$ The analysis however ambitiously assumes that a domestic redress mechanism serves as reasonable alternative to litigation in foreign courts.

${ }^{62}$ William M. O’Barr \& John M. Conley, 'Lay Expectations of the Civil Justice System', Law \& Society Review Vol. 22 (1988), p.137; Robin L. Pinkley, 'Dimensions of Conflict Frame: Disputant Interpretations of Conflict', Journal of Applied Psychology, Vol.75 (1990), p.117; Jonathan D. Casper, 'Having their day in court: Defendant evaluations of the fairness of their treatment', Law \& Society Review Vol.12 (1978), p.237; John Thibaut et al., 'Procedural Justice as Fairness', Stanford Law Review, Vol.26 (1974), p.1271.

${ }^{63}$ As argued earlier, it creates its won disadvantages to LDC.

${ }^{64}$ The issue is then what are 'similar' conditions. My argument assumes that, although 'similar' harms have occurred, the economic loss that follows those harms is much higher in a Western society than in a LDC society.

${ }^{65}$ Hilton v. Guyot, 159 U.S. 113 (1965); American Jurisprudence Second, Judgments, Vol.47, Section 1214 et seq.

${ }^{66}$ Recent examples are offered by bankruptcies filed as a result of the need or the risk to have to pay out numerous victims of negligent exposure to asbestos or consumers of products such as breast implants.

${ }^{67}$ I am referring to compensation of Australian customers in the Silicon Breast Implant Litigation and to the compensation of British victims in the Chapter 11 proceeding involving Federal Mogul, who had bought the British Turner and Newall soon before it filed for bankruptcy.

${ }^{68}$ The World Bank or another international body or organization could act as neutral administrator supervising the transaction.

${ }^{69}$ One strategy is perhaps to impose the implementation of measures aiming at improving human rights as condition to obtain aid. For a recent discussion on the conditionality system, Paul Mosley, John Hudson and Arjan Verschoor, 'Aid, Poverty Reduction and the 'New Conditionality', The Economic Journal, Vol.114 (2004), pp.217-43.

${ }^{70}$ Norms on the Responsibilities of Transnational Corporations and Other Business Enterprises with Regard to Human Rights, U.N. Doc. E/CN.4/Sub.2/2003/12/Rev.2 (2003). 